\title{
Konsep Pendampingan dalam Struktur Pemerintahan Indonesia: Mengapa Pendamping Lokal Desa Harus Ada?
}

\section{Concept of Assistance in Indonesian Government: Why Does a Village Need Local Assistant? \\ Jenny Yelina Rambe' ${ }^{1}$ Badaruddin ${ }^{1}$ \& Abdul Kadir ${ }^{2}$}

Magister Studi Pembangunan, Fakultas Ilmu Sosial dan Politik

Universitas Sumatera Utara, Indonesia

Program Sudi Administrasi Publik, Fakultas Ilmu Sosial dan Politik

Universitas Medan Area, Indonesia

Diterima: 27 Februari 2020; Disetujui: 09 April 2020; Diterbitkan: 01 Juli 2020.

\section{Abstrak}

Pembangunan desa menjadi prioritas program pembangunan nasional di Indonesia. Sejumlah langkah telah dilakukan seperti desentralisasi kewenangan, peningkatan kapasitas dan pendekatan anggaran. Langkah yang paling baru digunakan saat ini untuk mempercepat pembangunan desa adalah melalui program pendampingan desa. Setiap desa mendapatkan pendamping lokal desa untuk mengoptimalkan kinerja pemerintahan desa dan meningkatkan kapasitas masyarakat desa dalam proses pembangunan desa. Studi ini bertujuan untuk mengeksplorasi konsep pendamping desa dan peran pendamping lokal desa di Desa Batu Layan Kota Padangsidempuan Provinsi Sumatera Utara. Studi ini menggunakan penelitian kualitatif. Data didapatkan melalui wawancara mendalam, studi pustaka dan studi dokumentasi. Studi ini mendapatkan hasil bahwa konsep pendampingan desa diterapkan secara berjenjang mengikuti struktur pemerintahan di Indonesia untuk mendorong terealisasinya fungsi dan kewenangan setiap struktur pemerintahan dalam mencapai target pembangunan. Pendamping lokal desa dalam studi ini mampu melaksanakan fungsinya secara terampil melalui pendekatan komunikasi persuasif berdasarkan nilai-nilai lokal di daerah setempat.

Kata Kunci: Ekonomi, Politik, Inklusif, Ekstraktif, System Thinking

\begin{abstract}
Rural development is a priority of national development program in Indonesia. A number of measures have been taken such as decentralization of authority, capacity building, and budget approach. The most recently used action to accelerate rural development is through the village assistance program. Each village has a local village assistant to optimize the village administration performance and build the village community capacity in the rural development process. This research aims to explore the concept of village assistance program and the role of local village assistants in Batu Layan Village, Padangsidempuan City, North Sumatra Province. This research used qualitative research. The data were obtained through in-depth interviews, library research, and documentation studies. The research results indicated that the concept of village assistance was applied in stages following the governance structure in Indonesia to encourage the realization of the functions and authorities of each government structure in achieving development targets. Village local assistants in this research were able to perform their functions skillfully through a persuasive communication approach based on local values in the local area.
\end{abstract}

Keywords: Village Development, Village Assistance, Local Village Assistants, Village Government.

How to Cite: Rambe, J.Y Badaruddin \& Kadir, A (2020). Konsep Pendampingan dalam Struktur Pemerintahan Indonesia: Mengapa Pendamping Lokal Desa Harus Ada?. PERSPEKTIF, 9(2): 263-269

*Corresponding author:

ISSN 2085-0328 (Print)

E-mail: Lennvvelinarambe@gmail.com

ISSN 2541-5913 (online) 


\section{PENDAHULUAN}

Studi terhadap pembangunan desa telah menjadi perhatian di berbagai negara. Dalam mencapai pembangunan desa sejumlah model pendekatan telah digunakan seperti dana desa (Meutia and Liliana, 2018), peningkatan tata kelola kelembagaan desa yang efektif (Antlöv, Wetterberg and Dharmawan, 2016), program kemitraan antar lembaga formal dan informal (Rumkel, Sam and Umanailo, 2019), partisipasi dalam proses penganggaran dana desa (Chomariyah, Hudi and Ariyanto, 2016), pemberdayaan pengelola desa dalam sektor pariwisata desa (Jafari and Afrassiabi, 2013). Sejumlah model pendekatan tersebut dianggap relevan untuk diterapkan berdasarkan sistem pemerintahan dan kasus yang dihadapi.

Dalam literatur buku konsep desa di tempatkan sebagai unit terkecil dalam wilayah. Dalam sistem administrasi pemerintahan wilayah administrasi desa di kelola oleh pemerintahan desa. Pemerintahan Desa sebagai unit paling bawah dalam struktur pemerintahan Indonesia. Meski berada pada struktur terendah namun pemerintahan desa memiliki peran sentral dalam menentukan keberhasilan program-program pembangunan nasional. Peran sentral tersebut didasarkan pada "jarak" masyarakat dengan pemerintahan desa sangat dekat dan desa mendapatkan sejumlah anggaran untuk pembangunan desa. Dengan demikian segala bentuk pemberdayaan masyarakat untuk mencapai kesejahteraan dilakukan oleh pemerintahan desa. Fokus utama pemerintahan desa dalam membangun kesejahtraan masyarakat sesuai dengan target yang telah ditentukan oleh pemerintahan nasional yaitu berkaitan dengan pengentasan kemiskinan melalui pemberdayaan masyarakat dan pembangunan sarana-prasarana bagi kebutuhan masyarakat desa. Kondisi ini mengubah peran pemerintahan desa dari yang sebelumnya berfungsi sebagai unsur pelaksana menjadi berfungsi sebagai unsur pelaksana dan pengguna anggaran.

Pemerintahan Desa di Indonesia mendapatkan fungsi pengguna anggaran untuk pertama kalinya di tahun 2015. Secara nasional jumlah anggaran yang disediakan pada tahun tersebut berjumlah 20, 7 Triliun. Pada tahun 2016 meningkat menjadi 46,98 Triliun. Tahun 2017 dan 2018 menjadi 60 Triliun. Kemudian di tahun 2019 berjumlah 70
Triliun. Peningkatan anggaran yang diperuntukan bagi pemerintahan desa sejak tahun 2015 hingga tahun 2019 menjelaskan keseriusan pemerintah Indonesia untuk mengejar pembangunan nasional dari wilayah desa melalui pemerintahan desa

Untuk mencapai pembangunan desa, setiap desa mendampatkan pendampingan dalam bentuk sumber daya manusia profesional. Peraturan Pemerintah No. 47 Tahun 2015 tentang Perubahan Atas Peraturan Pemerintah No. 43 Tahun 2014 tentang Peraturan Pelaksanaan UndangUndang No. 6 Tahun 2014 Tentang Desa yang menyebutkan Pendamping Lokal Desa (PLD) yang bertugas di Desa untuk mendampingi Desa dalam penyelenggaraan pemerintahan, kerja sama, pengembangan badan usaha milik desa, dan pembangunan di tingkat desa (lihat pada pasal 129 ayat 1 dan pasal 128 ayat 2). Bertitik tolak dari tugas yang dimiliki pendamping lokal desa dapat dipahami konsep pembangunan desa yang ditempuh pemerintah Indonesia memfokuskan percepatan pembangunan desa.

Dalam kontek Indonesia terdapat sejumlah penelitian terdahulu yang telah memulai memberikan perhatian terhadap keberadaan tenaga pendamping dalam struktur pemerintahan desa seperti mengeksplorasi peran pendamping desa (Susanti, 2017; Ramanthia, 2015), tenaga pendamping profesional (Widiyarta, 2017), efektivitas (Susanti and Basri, 2015). Studi ini mengambil posisi yang berbeda dari penelitan sebelumnya yaitu mengambil fokus terhadap konsep pendamping dalam struktur pemerintahan Indonesia dan peran pendamping lokal desa di tingkat desa. Penelitian terdahulu telah mengeksplorasi peran pendamping desa namun belum menyentuh keberadaan pendamping dalam struktur pemerintahan Indonesia secara konseptual dan secara lebih khusus terhadap peran pendamping lokal desa. Terdapat perbedaan peran di antara pendamping desa dengan pendamping lokal desa. Pendamping lokal desa merupakan orang yang membantu pendamping desa. Sehingga kebaharuan studi ini terletak pada objek penelitian yang mengeksplorasi peran pendamping lokal desa.

Studi ini berasumsi pembangunan desa dengan pendekatan efektifitas kewenangan pemerintahan desa, anggaran desa dan tenaga 
pendamping maka berkonsekuensi terhadap percepatan pembangunan desa. Studi ini dilakukan untuk menguji asumsi tersebut dengan mengeksplorasi peran pendamping lokal desa terhadap pembangunan desa di Desa Batu Layan Kota Padangsidempuan Provinsi Sumatera Utara.

\section{METODE PENELITIAN}

Penelitian ini adalah penelitian deskriptif dengan pendekatan kualitatif. Informasi dan data didapatkan melalui wawancara, studi pustaka dan studi dokumentasi. Informan penelitian terdiri dari tiga jenis yaitu informan kunci, informan utama dan informan tambahan. Informan kunci dalam penelitian ini adalah Pendamping Lokal Desa (PLD) di Desa Batu Layan yaitu Ibu Misra. Informan utama pada penelitian ini adalah Kepala Desa Batu Layan yaitu Bapak Pontas Siregar, Kepala Urusan Pembangunan Desa Batu Layan yaitu Bapak Rahmat Ritonga dan Kadus I Desa Batu Layan yaitu Ibu Marjuliana Harahap. Informan tambahan pada penelitian ini adalah Masyarakat Desa Batu Layan yaitu Bapak Manap dan Bapak Alvin. Pengujian keabsahan atau kebenaran data menggunakan teknik Triangulasi. Lokasi penelitian berada di Desa Batu Layan yang beralamat di Jalan Raya Angkola Julu, Kecamatan Padangsidimpuan Angkola Julu, Kota Padangsidimpuan

\section{HASIL DAN PEMBAHASAN \\ Konsep Pendamping Desa Dalam Pemberdayaan Desa di Indonesia}

Pemberdayaan desa memberikan perhatian terhadap penguatan kapasitas lembaga formal, informal dan masyarakat untuk berpartisipasi dalam membangun desa melalui pendekatan pemberdayaan (lihat Rumkel, Sam and Umanailo, 2019: 1062). (Meutia and Liliana, 2018: 66) menyebutkan pemberdayaan sebagai upaya mengembangkan kemandirian pada berbagai aspek seperti pengetahuan, keterampilan, perilaku, pemanfaatan sumber daya dan lain sebagainya. Dalam konteks pemberdayaan desa dengan program pendampingan desa adalah memberikan dukungan tenaga ahli kepada pemerintahan desa untuk diberdayakan dalam memcapai tujuan pembangunan desa.

Secara konseptual Gitosaputro, Sumaryo and Rangga (2015: 75) memberikan definisi
"Pendampingan" sebagai kegiatan membantu masyarakat untuk belajar, menyelesaikan masalah, mengorganisasiakan diri dalam melakukan kegiatan aksinya. Dalam telaah isi Peraturan Menteri Desa, Pembangunan Daerah Tertinggal dan Transmigrasi Republik Indonesia Nomor 3 Tahun 2015 menyebutkan "Pendampingan" adalah tenaga pendamping profesional yang bertugas mendampingi desa dalam penyelenggaraan pembangunan desa dan pemberdayaan masyarakat desa.

Segala upaya telah digunakan dalam meningkatkan pembangunan desa yang bermuara pada tujuan meningkatkan kualitas hidup (kesejahteraan) masyarakat desa. Upaya lainnya yang digunakan dalam sistem pemerintahan Indonesia pada struktur pemerintahan desa ialah dengan mengusung program pendampingan desa sebagai bagian dari upaya pemerdayaan desa. Beberapa hasil penelitian terdahulu telah memberikan fakta bahwa program pemberdayaan berdampak efektif untuk mengurangi kemiskinan (lihat Datta, 2007: 60)

Dalam telaah peraturan perundangundangan Indonesia posisi Pendamping desa adalah sebuah jabatan di bawah kewenangan Kementrian Desa yang memiliki tugas untuk mendampingi pembangunan desa dalam rangka pengimplementasian Peraturan Menteri Desa, Pembangunan Daerah Tertinggal Dan Transmigrasi Republik Indonesia Nomor. 3 Tahun 2015 tentang Pendampingan Desa. Pendampingan desa dilakukan oleh pendamping desa yang terdiri dari tiga unsur yaitu: 1). Tenaga Pendamping Profesional, 2). Kader Pemberdayaan Masyarakat Desa, 3). Pihak ketiga seperti Lembaga Swadaya Masyarakat, Perguruan Tinggi, Organisasi Kemasyarakatan.

Berdasarkan telaah dari peraturan menteri desa Nomor. 3 Tahun 2015 tentang Pendampingan Desa didapatkan konseptualisasi pemikiran pendampingan desa bertujuan untuk mengefektifkan pemerintahan desa dalam mencapai pembangunan desa. Kedudukan pendamping desa dapat dijelaskan pada baga di bawah ini: 
Tabel: Pendampingan Desa Dalam Struktur Pemerintahan di Indonesia

\begin{tabular}{|c|c|c|}
\hline \multicolumn{3}{|c|}{ PENDAMPINGAN DESA } \\
\hline UNSUR & SUB UNSUR & KEDUDUKAN \\
\hline \multirow{4}{*}{$\begin{array}{l}\text { Tenaga } \\
\text { Pendamping } \\
\text { Profesional }\end{array}$} & Pendamping & Kecamatan \\
\hline & & \\
\hline & $\begin{array}{l}\text { Pendamping } \\
\text { Teknis }\end{array}$ & Kabupaten \\
\hline & $\begin{array}{l}\text { Tenaga Ahli } \\
\text { Pemberdayaa } \\
\text { n Masyarakat. }\end{array}$ & $\begin{array}{l}\text { Provinsi dan } \\
\text { Pemerintaha } \\
\text { n Pusat }\end{array}$ \\
\hline $\begin{array}{l}\text { Kader } \\
\text { Pemberdayaa } \\
\text { n Masyarakat } \\
\text { Desa }\end{array}$ & - & Desa \\
\hline Pihak ketiga & $\begin{array}{l}\text { Lembaga } \\
\text { Swadaya } \\
\text { Masyarakat } \\
\text { Perguruan } \\
\text { Tinggi } \\
\text { Organisasi } \\
\text { Kemasyarakat } \\
\text { an } \\
\text { Perusahaan. }\end{array}$ & $\begin{array}{l}\text { Wilayah } \\
\text { Indonesia }\end{array}$ \\
\hline
\end{tabular}

Sumber: Peraturan Menteri Desa, Pembangunan Daerah Tertinggal Dan Transmigrasi Republik Indonesia Nomor. 3 Tahun 2015 tentang Pendampingan Desa

Tabel di atas memperlihatkan tenaga pendampingan di sediakan pada setiap jenjang pemerintahan dimulai pada tingkat kecamatan hingga tingkat nasional. Efektifitas kinerja yang didapatkan dari keberadaan tersediannya tenaga pendampingan desa pada sisi lain konsekuensi pendekatan anggaran menjadi sorotan untuk membiayai honor para tenaga pendamping di setiap jenjang pemerintahan. Keberadaan pendamping lokal desa berada di bawah sub unsur pendamping desa yang berkedudukan di kecamatan. Pendamping lokal desa berada di tingkat desa untuk membantu pendamping desa di tingkat kecamatan. Kondisi ini menjelaskan struktur pemerintahan Indonesia mendapatkan dukungan pendampingan secara berjenjang untuk mewujudkan pembangunan yang diharapkan pada tiap jenjang pemerintahan.

\section{Penyebab Keberadaan Pendamping Lokal Desa}

Pada tahun 2015 dari Rp. 20,7 Triliun anggaran yang diperuntukan bagi pemerintahan desa rata-rata setiap pemerintahan desa mendapatkan anggaran berjumlah 280 juta. Tahun 2016 jumlah anggaran meningkat menjadi Rp. 46,98 Triliun dengan rata-rata pemerintahan desa mendapat Rp. 628 Juta (Kementerian Keuangan Republik Indonesia, 2017; Direktorat Jenderal Perimbangan Keuangan Indonesia, 2017). Anggaran pemerintahan desa pada tahun 2017 kembali meningkat menjadi menjadi Rp. 60 Triliun dengan ratarata setiap pemerintahan desa mendapat Rp. 800 Juta. Meski tahun 2018 anggaran desa tidak mengalami kenaikan dari tahun 2017 yaitu sebesar RP. 60 Triliun namun pada tahun 2018 terjadi penurunan anggaran bagi pemerintahan desa dengan rata-rata setiap desa mendapat Rp. 600 Juta (Kementerian Keuangan Republik Indonesia, 2018).

Dengan pengalaman penggunaan anggaran yang relatif baru serta ditopang dengan sumber daya manusia yang kurang memahami administrasi penggunaan anggaran di tingkat pemerintahan desa maka keberadaan anggaran tersebut menjadi permasalahan bagi pemerintahan desa. Permasalahan tersebut berkaitan dengan implementasi anggaran desa. Pemerintahan desa cenderung kurang memahami aspek peruntukan anggaran dan administrasi pelaporan penggunaan anggaran. Keadaan ini direspon pemerintah Indonesia melalui keberadaan "Pendamping Desa" yang berperan melakukan pendampingan penyelenggaraan pembangunan dan pemberdayaan masyarakat di desa (pasal 1112 Peraturan Menteri Desa, Pembangunan Daerah Tertinggal dan Transmigrasi Republik Indonesia Nomor. 3 Tahun 2015 tentang Pendampingan Desa.

Secaran teknis pendamping desa melakukan penguatan kapasitas terhadap pemerintahan desa, lembaga desa dan pemberdayaan masyarakat. Peran pendamping desa begitu luas dari dalam kontek pembangunan desa. luasnya peran tersebut terlihat pada pasal 12 ayat 1 yang menyebutkan dalam kegiatan pendampingan desa peran pendamping desa meliputi dari aspek perencanaan, pelaksanaan dan 
pemantauan. Bentuk partisipasi pendamping desa pada setiap aspek tersebut diwujudkan dalam bentuk tindakan asistensi, pengorganisasian, pengarahan, dan fasilitasi desa termasuk yang berkaitan dengan pertanggungjawaban penggunaan anggaran pemerintah desa.

Posisi desa di tengah arus globalisasi menurut Jati (2014) dapat memberikan dampak positif dan negatif terhadap desa. Program nasional yang ditetapkan pemerintah nasional untuk mencapai pembangunan desa melalui program pendampingan desa dapat memperkuat target pemerintahan desa dalam mewujudkan pembangunan desa. Pada sisi lain terdapat kekhwatiran publik mengenai perbedaan persepsi di antara aparatur pemerintahan desa dengan pendamping desa dalam melaksanakan pembangunan desa.

Pada kasus di Desa Batu Layan Kecamatan Padangsidimpuan Angkola Julu, Kota Padangsidimpuan peran pendamping desa dilaksanakan oleh pendamping lokal desa. Peran tersebut berdasarkan kedudukan masing-masing. Kedudukan pendamping desa berada di kecamatan. Setiap kecamatan memiliki jumlah desa yang tidak sedikit. Pada kasus ini kecamatan Padangsidimpuan Angkola Julu memiliki 8 desa dengan jumlah penduduk di tahun 2017 berjumlah 216.013 jiwa (Badan Pusat Statistik Kota Padangsidempuan, 2018). Setiap desa yang berada di kecamatan Padangsidimpuan Angkola Julu mendapatkan pendamping lokal desa yang berada di bawah kordinasi pendamping desa yang berkedudukan di tingkat kecamatan.

Secara lebih spesifik pada kasus di Desa Batu Layan yang merupakan salah satu desa di kecamatan Padangsidimpuan Angkola Julu persoalan utama yang dihadapi desa menurut kepala desa Batu Layan Bapak Pontas Siregar ialah berkaitan dengan partisipasi dan pengetahuan masyarakat yang masih sangat rendah dalam pembangunan desa. Menurut Pontas Siregar kieberadaan Pendamping Lokal Desa untuk mensosialisasikan informasi pembangunan, informasi segala peraturan perundang-undangan yang berkaitan dan meningkatkan partisipasi masyarakat dalam pembangunan melalui bentuk tindakan pendampingan (Wawancara, Pontas Siregar, 6 Juli 2019). Berdasarkan observasi di lapangan partisipasi masyarakat desa Batu Layan dalam pembangunan desa tergolong rendah. Hal ini dikarenakan mayoritas masyarakat desa sibuk dengan rutinitas masing-masing sebagai petani dan peternak. Selain itu budaya mengobrol di warung sambil minum teh atau kopi turut membentuk karakter masyarakat yang pasif untuk berpartisipasi dalam pembangunan desa. situasi ini memiliki kemiripan dengan karakteristik masyarakat tradisional dengan ciri-ciri memiliki kesibukan bertani ataupun berternak.

Masyarakat desa secara umum kurang memahami konsep pembangunan desa hingga bentuk-bentuk implementasi pembangunan desa. salah satu masyarakat desa Batu Layan bernama Alvin membenarkan kondisi ini. Alvin sangat berharap dapat memperoleh penjelasan secara rinci mengenai keterlibatan masyarakat desa dalam konsep pembangunan desa (Wawancara, Alvin, 7 Juli 2019). Terhadap realitas kondisi pengetahuan masyarakat yang sangat minim mengenai tata cara berpartisipasi dalam pembangunan desa menurut Pendamping Lokal Desa bernama Ibu Misra pada kondisi ini pendamping lokal desa bekerja. Pendamping Lokal Desa berfungsi untuk mengubah keadaan masyarakat dari yang tidak tahu atau yang pasif menjadi aktif untuk merespon berbagai kegiatan-kegiatan desa. Misra menyebutkan secara konstitusi Pendamping Lokal Desa dalam kontek pembangunan desa memiliki tugas untuk terlibat pada aspek perencanaan, pelaksanaan, pemantauan dan evaluasi. Kemudian pada berbagai kegiatan dalam melakukan pemberdayaan masyarakat desa (Wawancara, Misra, 3 Juli 2019).

Wawancara yang dilakukan dengan kepala desa Batu Layan (Pontas Siregar) menyebutkan dalam melaksanakan tugas dan fungsi Pendamping Lokal Desa ibu Misra pada berbagai kegiatan mengambil posisi sebagai pelatih, mediator, fasilitator, penggerak, komunikator, informan, kendali, narasumber (Wawancara, Pontas Siregar, 6 Juli 2019). Salah satu masyarakat desa bernama Bapak Manap menyebutkan informasi mengenai pembangunan desa diketahui olehnya melalui media papan informasi (Wawancara, Manap, 7 Juli 2019). Apa yag disebutkan Manap mengenai informasi yang diperoleh dari papan informasi merupakan sebagai bentuk keterbukaan informasi yang telah di tingkatkan pemerintah desa dengan bekerja 
sama dengan pendamping lokal desa. Pada kondisi ini menjelaskan tercapainya kondisi dari yang sebelumnya masyarkat yang tidak mengetahui informasi pembangunan desa berubah menjadi tahu informasi pembangunan desa melaui media papan informasi.

Kegiatan dengan bentuk pelatihan dan pemberdayaan telah berdampak pada meningkatnya partisipasi masyarakat dalam menghadiri pertemuan formal di desa. interaksi sosial dalam, bentuk komunikasi pembangunan menjadi topik pembicaraan yang pada akhirnya meningkatkan pengetahuan masyarakat desa terhadap konsep pembangunan desa. Secara berkala seluruh kegiatan yang diselenggarakan pemerintahan desa dengan Pendamping Lokal Desa telah mampu mengubah persepsi masyarakat dalam memandang pembangunan desa melalui pendekatan anggaran desa dan pemberdayaan masyarakat. Asumsi masyarakat terhadap alokasi anggaran desa yang keliru dalam peruntukan akhirnya diketahui distribusinya melalui sejumlah program pembangunan desa berbentuk fisik dan pemberdayaan masyarakat.

\section{SIMPULAN}

Konsep pendampingan pada setiap struktur pemerintahan di Indonesia dari tingkat nasional hingga pada tingkat desa sebagai bentuk keseriusan pemerintah Indonesia dalam mengawal tercapainya pembangunan di setiap tingkat pemerintahan. Saat ini konsentrasi perhatian tersebut berada pada tingkat desa melalui penyediaan tenagatenaga profesional untuk mengoptimalkan pemerintahan desa dalam penggunaan anggaran dan pemberdayaan masyarakat untuk pembangunan desa. Pendamping lokal desa sebagai unsur pendukung tugas pendamping desa di tingkat kecamatan. Dengan mempertimbangkan jumlah desa pada setiap kecamatan berbeda dan persoalan yang dihadapi desa berbeda-beda. Keberadaan pendamping lokal desa mutlak diperlukan untuk membantu pendamping desa di tingkat kecamatan dalam menjangkau seluruh desa. Pada kasus di Desa Batu Layan Kecamatan Padangsidimpuan Angkola penelitian ini mendapatkan temuan secara bertahap terjadi transformasi partisipasi masyarakat dari yang semula pasif berupah menjadi aktif dalam program pembangunan desa. Proses tersebut sebagai dampak dari peran Pendamping Lokal Desa yang responsif dalam mengimplementasikan fungsinya dan mampu bersinergi dengan pemerintahan desa melalui pendekatan informal berdasarkan nilai-nilai kearifan lokal.

\section{DAFTAR PUSTAKA}

Antlöv, H., Wetterberg, A. and Dharmawan, L. (2016) 'Village Governance, Community Life, and the 2014 Village Law in Indonesia', Bulletin of Indonesian Economic Studies, 52(2), pp. 161-183. doi: 10.1080/00074918.2015.1129047.

Chomariyah, Hudi, N. and Ariyanto, B. (2016) 'Participation Principle On The 2014 Village Law In Coastal Village', International Journal of Business, Economics and Law, 10(4), pp. 33-40. Available at: http://ijbel.com/wpcontent/uploads/2016/09/K10_204.pdf.

Datta, D. (2007) 'Sustainability of community-based organizations of the rural poor: Learning from Concern's rural development projects, Bangladesh', Community Development Journal, 42(1), pp. 47-62. doi: 10.1093/cdj/bsi093.

Gitosaputro, Sumaryo and Rangga, K. K. (2015) Pengembangan dan Pemberdayaan Masyarakat: Konsep, Teori dan Aplikasinya Di Era Otonomi Daerah. Yogyakarta: Graha Ilmu.

Indonesia, R. (2017) Peraturan Menteri Keuangan Republik Indonesia No. 22/PMK.07/2017 Tentang Perubahan Rincian Dana Desa Menurut Kabupaten/Kota Tahun Anggran 2018. Indonesia.

Jafari, H. and Afrassiabi, M. (2013) 'The Role of Empowering Village Managers in Tourism Industry: A Case Study of Bojnord Villages', International Journal of Academic Research in Business and Social Sciences, 3(8), pp. 483495. doi: 10.6007/ijarbss/v3-i8/173.

Jati, W. R. (2014) 'Globalisasi dan Kemiskinan Desa: Analisa Struktur Ekonomi Politik Pedesaan', Jurnal penelitian politik, 11(2), pp. 17-26. doi:

https://doi.org/10.14203/jpp.v11i2.198.

Keuangan, D. J. P. (2017) Rincian Alokasi Transfer Ke Daerah Dan Dana Desa Provinsi/Kabupaten/Kota Dalam APBN T.A. 2018. Jakarta. Available at: http://www.djpk.depkeu.go.id/wpcontent/uploads/2017/11/Rincian-AlokasiTKDD- TA-2018-1.pdf.

Keuangan, D. J. P. (2018) Rincian Alokasi Dana Desa Provinsi/Kabupaten/Kota Dalam APBN T.A. 2019. Jakarta. Available at: http://www.djpk.kemenkeu.go.id/wpcontent/uploads/2018/10/DANA-DESA.pdf. 
Meutia, I. and Liliana (2018) 'The Management of Village Fund Finances', Jurnal Dinamika Akuntansi, 9(1), pp. 63-81. doi: 10.15294/jda.v9i1.12009.

Ramanthia (2015) 'Kinerja Pendamping Desa Dalam Pemberdayaan Masyarakat Desa (Studi Di Desa Bukit Rawi Kecamatan Kahayan Tengah Kabupaten Pulang Pisau)', Jurnal Ilmu Sosial, Politik, dan Pemerintah (JISPAR), 4(2), pp. 1-11. Available at: https://jispar.wordpress.com/2018/02/02/ kinerja-pendamping-desa-dalampemberdayaan-masyarakat-desa/.

Rumkel, L., Sam, B. and Umanailo, M. C. B. (2019) 'Village Head Partnership, Village Consultative Body and Customary Institution in Village Development', International Journal of Scientific \& Technology Research, 8(8), pp. 1058-1063. Available at: https://www.researchgate.net/publication/ 335377205_Village_Head_Partnership_Villag e_Consultative_Body_and_Customary_Institu tion_in_Village_Development.
Susanti, M. H. (2017) 'Peran Pendamping Desa Dalam Mendorong Prakarsa Dan Partisipaso Masyarakat Menuju Desa Mandiri Di Desa Gonoharjo Kecamatan Limbangan Kabuaten Kendal', Integralistik, 28(1), pp. 29-39. Available at: https://journal.unnes.ac.id/nju/index.php/i ntegralistik/article/view/11809.

Susanti, R. and Basri (2015) 'Efektivitas Pendamping Desa Dan Partisipasi Masyarakat Dalam Pembangunan Infrastruktur Pedesaan Di Desa Sekodi Kecamatan Bengkalis Kabupaten Bengkaslis', Jurnal Jom FISIP, 2(1), pp. 1-15. Available at: https://jom.unri.ac.id/index.php/JOMFSIP/a rticle/view/5057.

Widiyarta, A. (2017) 'Efektifitas Tenaga Pendamping Profesional Dalam Pemanfaatan Dana Desa Guna Mendorong Pemberdayaan Masyarakat Desa', Dinamika Governance: Jurnal Ilmu Administrasi Negara, 7(1), pp. 115. Available at: http://eprints.upnjatim.ac.id/7361/. 